\title{
O PAPEL DO PROFESSOR DE PRIMEIRAS LETRAS NO MANUAL DE PEDAGOGIA DE JEAN BAPTISTE DALIGAULT: REFLEXÕES SOBRE A FORMAÇÃO DE VIRTUDES E VALORES
}

\author{
Olivia Rochadel ${ }^{1}$ \\ Leonete Luzia Schmidt ${ }^{2}$
}

\begin{abstract}
RESUMO
Este artigo objetiva identificar o papel do professor, refletindo sobre ele, a partir das definições contidas no manual Cours Pratique de Pédagogie, do francês Jean Baptiste Daligault. A obra analisada foi a segunda edição da tradução realizada na província de Santa Catarina. Este manual foi distribuído aos inspetores e aos professores de instrução pública elementar pelo governo provincial, na segunda metade do século XIX. Considerando que esta atitude do governo concebe o manual como uma obra relevante para a formação dos professores da província, e também que Santa Catarina, ainda, conta com poucas pesquisas sobre a educação escolar no século XIX, a compreensão do papel do professor definido por Daligault pode contribuir para ampliar o conhecimento dessa história. Assim, partindo do entendimento de que a educação é resultado de um processo histórico, das relações que os homens mantêm entre si e com a natureza, constata-se que o papel do professor descrito por Daligault é o de formar as futuras gerações dentro dos ideais da sociedade moderna de ordem burguesa, caracterizada como civilizada e coerente com o projeto de Estado nacional brasileiro, em processo de construção naquele momento.
\end{abstract}

Palavras-chave: Manual de Pedagogia; Jean Baptiste Daligault; Papel do professor; História da Educação Catarinense.

\section{THE ROLE OF THE FIRST LETTERS TEACHER IN THE PEDAGOGICAL MANUAL OF JEAN BAPTISTE DALIGAULT: REFLECTIONS ABOUT VIRTUES AND VALUES FORMATION}

\begin{abstract}
This article aims to identify the teacher's role, reflecting on it, from the definitions contained in the manual Cours Pratique de Pédagogie, by Frenchman Jean Baptiste Daligault. The work analyzed was the second edition of the translation carried out in the province of Santa Catarina. This manual was distributed by the provincial government to inspectors and to teachers of elementary public instruction in the second half of the 19th century. Considering that this attitude of the government devises the manual as a relevant work to the teachers training of the province, and also that Santa Catarina still has few research on school education in the nineteenth century, the understanding of the teacher's role defined by Daligault can contribute to increase the knowledge of this history. Thus, starting from the understanding that education is the result of a historical process, of the relations that the human beings maintain between themselves and with nature, it is verified that the teacher's role described by Daligault is that of forming the future generations within the ideals of the modern society of the bourgeois order, which is characterized as civilized and coherent with the project of Brazilian national state, in a construction process at that moment.
\end{abstract}

Keywords: Pedagogical Manual; Jean Baptiste Daligault; Teacher's role; History of Catarinense Education. 


\section{Introdução}

No Brasil, a discussão voltada à formação de professores emerge, ainda que de forma incipiente, após a Independência, com a primeira Lei das Escolas de Primeiras Letras, aprovada em 15 de outubro de 1827, que justificava a necessidade de organizar a instrução popular. Nesse período, a instrução pública, vista como um dos elementos no processo de construção do Estado nacional brasileiro, tem sua direção pautada pela sociedade moderna de ordem burguesa caracterizada como civilizada. "[...] civilizar era, em especial, construir uma estrutura mental moderna, espraiar e fazer incorporar a ética social burguesa da possibilidade de se progredir pelo trabalho, ao desenvolver-se talentos e potencialidades individuais" (SCHMIDT; SCHAFASCHEK; SCHARDONG, 2012, p. 108).

O trabalho, nesse contexto, passa a ser a base da estrutura econômica, em que os que têm menos (classes baixa e intermediária) trabalham mais para alcançar melhor classificação social. Nesse sentido, ele foi o grande propulsor da escola como um local institucionalizado, consequentemente, o trabalho do professor deveria promover uma formação para a civilidade e a moralidade previstas. Saber ler e escrever tornou-se o passaporte para a modernização e possibilidade de ascensão social, marcando o momento de passagem para um novo mundo, o da cultura letrada. A escola, definida como instrumento para essas ações, relacionava-se "com a construção de um novo projeto político, econômico e cultural", que moralizaria os alunos através da transmissão de bons costumes e de condutas morais e cívicas (SCHMIDT; SCHAFASCHEK; SCHARDONG, 2012, p. 38).

Souza, Valdemarin e Almeida (1998) observam:

A partir desta nova possibilidade de relacionar-se com o mundo físico, a educação é entendida como um ato de emancipação humana, uma vez que a razão, adequadamente orientada por procedimentos ensináveis, criaria a possibilidade de construção de uma sociedade harmônica, espelhamento do progresso obtido com relação ao saber e ao desenvolvimento material (SOUZA; VALDEMARIN; ALMEIDA, 1998, p. 90).

Assim, a educação passa a ser uma forma eficaz de civilizar o povo brasileiro a partir do ideal do Estado burguês, que previa a estratificação das classes sociais. O conhecimento sobre as leis e o respeito a elas dava sustentação a este ideal. Ademais, a estrutura social exige a construção de uma nova sociabilidade, em uma ordem social estratificada, mas fundamentada para os desfavorecidos, através da religião, em movimentos de aceitação e subordinação à criação de um sistema baseado na ordem do capital.

Sobre essa configuração da sociedade brasileira, Veiga (2002) lembra que:

No contexto do século XIX, por meio da monopolização dos saberes elementares pelo Estado, observa-se, portanto, a produção de um dispositivo de inclusão de todos na civilização; neste sentido, a identidade de escolarizado/não-escolarizado produziu novas relações de interdependência entre os grupos sociais, indicando outra configuração social. Como na monopolização da força física, a monopolização dos saberes pelo Estado diluiu as relações de saber na sociedade, particularmente entre as populações pobres, fazendo desencadear todo um movimento de contenção dos seus saberes e, com isso, tornando possível a delegação da educação dos seus filhos ao Estado (VEIGA, 2002, p. 98-99). 
Dessa forma, a civilidade existe para todos que compõem a sociedade brasileira, porém seu caráter possui diferentes configurações para cada grupo social. Para os mais pobres, significa viver em sociedade de forma ordeira; para os ricos, ocupar um lugar digno na sociedade. O Estado, como um dos pilares desse novo modelo, utiliza-se da educação escolar para a construção da hegemonia em torno desse novo projeto, dando a cada segmento social a dosagem adequada de conhecimento dessa nova configuração social.

É nesse contexto que o manual de Pedagogia de Jean Baptiste Daligault foi trazido para o Brasil, pouco tempo após sua publicação na França. A aquisição do manual por dirigentes provinciais de diferentes regiões do país evidencia influência francesa no processo de formação de professores brasileiros. A aquisição e tradução desse manual pela província catarinense, no início da segunda metade do século XIX, e, posteriormente, sua distribuição para inspetores e professores das escolas públicas de instrução elementar locais demonstra que os dirigentes dessa província consideraram haver nele contribuições para a educação a ser oferecida pelas escolas públicas em processo inicial de organização em Santa Catarina, e, consequentemente, para a construção do Estado nacional brasileiro. Isso porque o ideal de nação em constituição "requeria uma sociedade formada por indivíduos unidos pelo governo central e pela lei", mediante ações a serem implementadas nas diferentes províncias do Império através de seus dirigentes locais. Era preciso criar entre os habitantes do Império o sentido de pertencimento à nação brasileira.

Trevisan e Pereira (2011, s./p.), em pesquisa sobre os manuais de ensino franceses utilizados no Brasil para leitura e escrita, entre 1851 e 1966, afirmam que, embora tenham sido encontrados "manuais de ensino para a formação de professores de autoria de norteamericanos, portugueses, franceses e espanhóis", a "maior recorrência é de manuais escritos por franceses". De acordo com Bastos (2008), as primeiras manifestações da adoção do ideal francês como modelo podem ser percebidas através da tradução de autores franceses, da apropriação destes pela elite intelectual, do domínio da língua francesa como significativo para a elite e, na educação, a adesão do estudo da língua francesa e a criação do currículo a partir do modelo francês (instituindo a adoção de materiais franceses como necessária).

Para esta autora, um dos fatores facilitadores para a adoção de materiais escolares franceses no Brasil é a formação de professores brasileiros em escolas normais francesas. Assim, habituado com a língua francesa e seus autores, o trabalho do professor acabava repercutindo a cultura apropriada em seu processo de formação na França. Outro fator indicado por Bastos (2008) é a entrada de livros franceses no Brasil. Também a propagação da escola e a necessidade de que os métodos de ensino atendessem à necessidade de grupos numerosos de alunos, pois os métodos vigentes no Brasil, até então, eram eficazes apenas para o ensino individualizado, que acontecia nas casas, e insuficientes para atender turmas numerosas em escolas. A mesma autora explica, ainda, que "a adoção dos manuais escolares franceses, no Brasil e em outros países, faz parte de um projeto de expansão do mercado editorial e livreiro, mas também de universalização de uma cultura escolar identificada com a modernidade" (BASTOS, 2008, p. 52).

Além das referências apontadas, Saviani (2009, p. 143) diz que Paris foi quem instituiu a primeira Escola Normal de que se tem registro, em 1795. Tempos depois, no século XIX, outros países, como Itália, Alemanha, Inglaterra e Estados Unidos, investiram em suas primeiras Escolas Normais, o que pode ter contribuído para que manuais franceses fossem tomados com referência.

Identificar e refletir sobre o papel atribuído ao professor de primeiras letras no manual Cours Pratique de Pédagogie, de Jean Baptiste Daligault, ou, como foi traduzido para o português, Curso Prático de Pedagogia, torna-se relevante para a compreensão da história da educação brasileira, e, de modo específico, a catarinense. A obra analisada foi 
traduzida em Santa Catarina por Fran de Paulicéia Marques de Carvalho e publicada em 1870. Trata-se de uma pesquisa de natureza histórica que, segundo Thompson (1981, p. 57), "[...] tem como objetivo reconstituir, explicar e compreender seu objeto: a história real". E esta "[...] é resultado da luta de classes, um contínuo tecer e destecer de alianças, rupturas e enfrentamentos coletivos".

O mesmo autor ressalta, ainda, que uma pesquisa nessa perspectiva "[...] consiste num diálogo entre conceito e evidência, um diálogo conduzido por hipóteses sucessivas, de um lado, e a pesquisa empírica, do outro" (THOMPSON, 1981, p. 49). Para a formação dessa lógica, é preciso que os pesquisadores detenham sua atenção não só para compreender o objeto de sua pesquisa, como também para conhecer os caminhos que farão chegar até ele, porque

o passado humano não é um agregado de histórias separadas, mas uma soma unitária do comportamento humano, cada aspecto do qual se relaciona com os outros de determinadas maneiras, tal como os atores individuais se relacionavam de certas maneiras (pelo mercado, pelas relações de poder e subordinação, etc.). Na medida em que essas ações e relações deram origem a modificações que se tornam objeto de investigação racional, podemos definir essa soma como um processo histórico, isto é, práticas ordenadas e estruturadas de maneiras racionais (THOMPSON, 1981, p. 50-51, grifos do autor).

Por esse entendimento, busca-se identificar e refletir sobre o papel do professor, a partir das definições contidas no manual de Pedagogia de Jean Baptiste Daligault.

\section{O papel do professor de primeiras letras no manual de daligault}

As leituras em Daligault evidenciam que o professor deve ser, para os alunos e para a sociedade, um exemplo de virtudes e valores que favoreçam a organização social prevista pela religião e pelo Estado. Assim, juntamente com as figuras materna e paterna, impediria os descaminhos das futuras gerações.

Nessa perspectiva, a disciplina ganha destaque no papel do professor; como algo a ser praticado por ele durante as aulas, através do cumprimento de horários e dos meios disciplinares a serem utilizados com os alunos, como: impor silêncio e obediência às ordens e definir punições ou gratificações. Ou seja, a disciplina é instituída por Daligault como a forma através da qual os professores devem organizar as Escolas de Primeiras Letras.

Na tese intitulada Sentidos da Profissão Docente, Silva (2004) identifica, na história da formação de professores do Brasil e de Portugal, que "a normatização das condutas, a regulação do corpo e do comportamento social acompanham os profissionais do ensino, assim como se vê nos quadros militares, desde o ingresso na Escola Normal, estendendo-se até mesmo após a aposentadoria" (SILVA, 2004, p. 120). Daligault, por sua vez, ao definir a disciplina como forma de organização da escola, é coerente com os modelos das escolas de formação de professores instaladas no Brasil e em Portugal durante o século XIX.

Essa organização com a disciplina, conforme descrita por Daligault, é justificada pela necessidade de os alunos tornarem-se futuros cidadãos que zelem pela religião, respeitem as figuras políticas (governantes da província) e religiosas (padres, bispos, etc.), e tenham inteligência para ler, escrever e fazer cálculos. Além disso, aqueles a quem a vida reserva o trabalho duro devem desempenhar bem suas funções por meio do bom condicionamento físico e da aceitação da sua condição social. Para assegurar isso, Daligault apresenta no 
manual a forma como devem ser organizadas as Escolas de Primeiras Letras como também o trabalho do professor.

Segundo ele, o papel do professor pode ser agrupado em torno de duas questões: na formação de virtudes e valores e na formação intelectual (DALIGAULT, 1870). A formação de virtudes e valores não é tratada por Daligault em um capítulo específico, mas durante toda a obra. No caso da formação intelectual, há uma parte do manual específica para este fim, onde ele descreve métodos, conteúdos, organização de horários, entre outras questões não abordadas neste texto.

\section{A formação de virtudes e valores como papel do professor}

O processo de constituição do Brasil como nação tinha a sociedade burguesa como ideal a ser seguido. Havia, portanto, a necessidade de assegurar que esse ideal fosse incorporado, se não por toda, pela maioria da população, possibilitando, assim, sua efetiva implantação. Nessa direção, a escola a ser oferecida para a população trabalhadora precisava assegurar as bases desse modelo. Sendo o professor o sujeito que conduziria o processo de instrução/educação na escola, seu papel teria que contemplar também esses princípios. $\mathrm{O}$ manual de Pedagogia de Daligault surge nesse contexto. Além de ser modelo/orientador de atividades práticas para o professor, é também direcionador político do projeto de nação em constituição.

Definidas por Daligault como modos de ser e estar, as virtudes podem ser identificadas nas orientações aos professores sobre modos de andar e de vestir, no cumprimento dos horários de entrada e saída da escola, na definição de datas de avaliações, nas gratificações, no modo de fazer os alunos aceitarem as punições e na realização das orações coletivas, conforme estabelecido pelo professor.

Desse modo, o professor

[...] vê engrandecer-se, a elevar-se o seu importante papel: é ele realmente quem põe os meninos na posse das faculdades intelectuais, com que a natureza os dotara: é ele quem lhes ensina a pensar, refletir, raciocinar; é ele quem orna o seu espírito com esses conhecimentos, cuja aplicação as diversas necessidades da vida reclamam a cada passo; é ele enfim quem lhes abre os umbrais do palácio da razão, para as maravilhas da natureza, e para os prodígios da indústria humana (DALIGAULT, 1870, p. 19).

Assim, Daligault coloca o professor numa condição diferente de outros sujeitos sociais, atribuindo a ele o papel de formador intelectual e moral de meninos a ele confiados. A virtude do professor precisa ser, ao mesmo tempo, exemplo a ser seguido e base dos ensinamentos para assegurar uma formação de sujeitos educados e ordeiros.

No prólogo do manual, o professor de primeiras letras é identificado como um instrumento para a civilização, mas dentro dos princípios religiosos da Igreja Católica. Desta forma, tem seu trabalho compreendido como fundamental para tornar as crianças aptas a conviver em sociedade. 
O principal objeto da missão do Professor é conduzir à virtude os meninos, que lhe são confiados. Achando-se ele obrigado a despertar e fecundar sua inteligência, e devendo, tanto quanto estiver em seu alcance, favorecer o desenvolvimento de suas entidades físicas, não pode contudo limitar a isto somente os seus esforços, sem confundir, por um erro funesto e culpável negligência, os meios com o fim. Conhecer a Deus e observar os seus preceitos tal é a destinação para que o homem foi criado, tal objeto que a consciência e a religião proclamam como a única coisa necessária (DALIGAULT, 1870, p. 13).

Há uma ênfase, em diferentes momentos do manual, na figura de Deus como imagem a ser seguida e razão da existência humana. Assim, a religião é colocada como expressão de Deus para o homem. O professor, tendo a responsabilidade pela formação das crianças, terá que ser ele imagem desse Deus para levar a obra do Criador a todas as crianças a ele confiadas. Para Daligault,

mais importante que a educação intelectual, que esclarece o espírito, a educação moral forma o coração, isto é corrige os defeitos do caráter, destrói ou previne os maus hábitos, dispõe a vontade, para seguir os preceitos da virtude em uma palavra, assegura a observância da lei que todo o homem, que vive na sociedade, acha gravada no fundo de seu coração, a qual se chama lei natural. Esta lei emana evidentemente do próprio Deus, porque se não fosse assim ela não seria mais do que uma inexplicável ilusão do espírito humano (DALIGAULT, 1870, p. 247, grifos do autor).

Para este autor, não há possibilidade de a vida social ser organizada sem a religião. As qualidades humanas são garantidas para aqueles que seguem a lei divina traduzida pela religião católica.

[...] a lei religiosa propriamente tal, reproduz exatamente os preceitos da lei natural. Sem dúvida a lei religiosa completa, eleva, enobrece e aperfeiçoa os deveres, que a lei natural nos impõe, ela os esclarece com sua divina luz, e facilita o cumprimento deles pelos meios espirituais que põe à nossa disposição, mas tanto esta como aquela tem um único e idêntico objeto, que é: o amor do bem e a prática da virtude (DALIGAULT, 1870, p. 247).

Nessa perspectiva, para Daligault, mais do que saber ler e escrever, é preciso que os alunos tenham conhecimento das virtudes, apropriando-se delas através da educação moral e religiosa a ser transmitida pelo professor, para quem o magistério deve ser assumido por vocação, expressão da vontade de Deus. 
O que eleva, porém, sobretudo o magistério, é a magnitude dos interesses, que lhe são confiados. Encarregado de educar as gerações novas, o Preceptor completa, por assim dizer, a obra de Deus. Ele é o depositário dessa autoridade santa, conferida ao pai de família pela Providência, a natureza, e as leis. Influi de maneira mais eficaz no destino temporal e eterno dos meninos, que em torno dele se reúnem. Segundo o modo porque preenche o seu ministério sagrado, torna-se para a Sociedade um poderoso instrumento de civilização e prosperidade, ou um flagelo destrutor, derramando por toda a parte os germes de corrupção e de morte (DALIGAULT, 1870, p. 18).

Diante desse entendimento, ou o professor é depositário de virtudes que lhe conferem competência para ser instrumento de civilização nos moldes almejados pelos dirigentes do período, ou, se não possui virtudes, não é digno de tão nobre missão e suas ações servirão para o descaminho das futuras gerações. Esse entendimento evidencia que é responsabilidade do professor fazer com que os alunos compreendam a religião e a divisão social entre ricos e pobres como ordens divinas, e, portanto, não devem ser questionadas. Uma formação sem essa base religiosa e moral gera alunos que não respeitam normas de convívio social e, por conseguinte, tornam-se um problema social.

O Curso Prático de Pedagogia, tomado como referência para a formação do professor de instrução elementar, passa a ser um instrumento que contribui para a formação do Estado brasileiro, atendendo aos princípios da ideologia dominante daquele período. $\mathrm{O}$ professor torna-se modelo de conduta, especialmente para a parcela da população mais pobre que passava a frequentar a escola naquele momento e teria que ser conduzida dentro de determinados princípios.

A província catarinense havia definido a religião como parte dos ensinamentos a serem oferecidos pela escola de instrução elementar desde as primeiras leis sobre a instrução pública (1835 e 1836). Embora o ensino fosse laico na França, no momento da escrita do manual de Pedagogia, no início da década de 1850, isso não impediu que os dirigentes provinciais o tivessem como modelo de civilização. Schmidt, Schafaschek e Schardong (2012), em leitura dos jornais publicados em Desterro ${ }^{3}$, no século XIX, mostram que estes destacavam a laicidade do ensino na França, ao afirmar que

a discussão do modelo educacional francês era questão presente com regularidade nos periódicos impressos em Desterro, na segunda metade da década de 1850. A preocupação maior era mostrar os estragos que os princípios revolucionários haviam criado na educação francesa (SCHMIDT; SCHAFASCHEK; SCHARDONG, 2012, p. 220).

Segundo as autoras, as discussões dos jornais apuravam:

Um dos grandes defeitos da instrução refinada, e da civilização quase excessiva da França, é de ter feito desaparecer o sentimento religioso, à proporção que a inteligência se desenvolvesse, a instrução primária, particularmente, serviu de propaganda ao espírito de revolta porque tem ela negligenciado de apresentar-se debaixo dos auspícios da religião (SCHMIDT; SCHAFASCHEK; SCHARDONG, 2012, p. 219).

O manual enfatiza a religiosidade, dizendo que o professor precisa fazer com que seus alunos atendam aos pressupostos sociais e religiosos da época: ter inteligência para ler, 
escrever e fazer cálculos, possuir habilidades físicas, ter uma prática social embasada em virtudes e, sobretudo, ser cristão.

$\mathrm{Na}$ terceira parte do manual, intitulada Educação Moral e Religiosa ${ }^{4}$, Daligault apresenta definições sobre o que são virtudes religiosas.

As virtudes religiosas, cuja cultura é da mais alta importância para os meninos em especial, são: $1^{\circ}$ a piedade, ou o amor de Deus, e o respeito à sua lei; $2^{\circ}$ a caridade, ou o amor do próximo por amor de Deus; $3^{\circ}$ a humildade, ou o sentimento profundo que o verdadeiro cristão tem a respeito de sua própria fraqueza (DALIGAULT, 1870, p. 277, grifos do autor).

A transmissão das virtudes religiosas, nesse contexto, compreendia disseminar a crença em um Deus que é superior aos homens, a benevolência entre si e para com Deus, e reconhecer-se em subserviência ao Deus. Para isto o professor deve "estudar o caráter dos meninos", banir os defeitos que forem apresentados por eles, assegurando que adquiram e conservem as virtudes que são essenciais, e aplicar, no cotidiano das escolas de primeiras letras, diversas formas para fortalecer o "instinto moral e o sentimento religioso" (DALIGAULT, 1870, p. 248). De acordo com o autor,

Oito meios há que nos parecem principalmente próprios para desenvolver nos meninos o instinto moral e o sentimento religioso. São os seguintes: $1^{\circ}$ exemplo do Mestre; $2^{\circ}$ histórias edificantes; 3 - contos morais e cânticos; 4ㅇ exercícios religiosos; 5 consideração das maravilhas da natureza; 60 lembrança viva e contínua da presença de Deus; 7o (temor de contrariar a ordem de Deus, ou desagradá-lo) e temor dos castigos, que ameaçam a transgressão da lei Divina; 8o finalmente, esperança firme das recompensas prometidas, ou assegurá-las à virtude (DALIGAULT, 1870, p. 277-278).

O professor, além de ser exemplo, deve fazer com que as atividades sejam caminhos através dos quais as virtudes possam ser exercidas na escola. Não esquecendo nunca de ter a figura de Deus como ente superior que rege aqueles que forem virtuosos e castiga aqueles que assim não forem.

As virtudes religiosas ganham mais consistência se incorporadas a elas as virtudes morais. No manual, Daligault define as virtudes morais como: pureza de costumes, piedade filial, amor fraterno, probidade, benevolência e polidez, respeito aos superiores e aos mais velhos, e respeito à lei e aos magistrados.

A pureza de costumes é descrita, na página 261, como a qualidade através da qual as conversas impróprias para a idade dos estudantes exigem a separação dos meninos e meninas nas escolas. A virtude piedade filial, que se resume em amor e respeito aos pais, é descrita na página 263. O amor fraterno, apresentado na página 265, consagra a piedade filial, pois se consubstancia em amor e respeito aos irmãos, aqueles que são filhos do mesmo pai e da mesma mãe. Para explicar como acontece o cumprimento da virtude probidade, descrita na página 267 do manual, Daligault usa o exemplo do "direito de propriedade" que o professor deve transmitir aos alunos, afirmando que toda propriedade é "fruto do trabalho, ou da pessoa que possui, ou dos que lhe transmitiram seus títulos". Ao explicar essa virtude, Daligault enfatiza o roubo como um comportamento impróprio para aqueles que o compreendem, e salienta que os bens públicos ou do Estado devem ser zelados por todos. Benevolência e polidez, na página 271, asseguram a boa convivência entre os alunos, a partir do entendimento de que todos possuem necessidades em comum e, por isso, não são 
necessários conflitos. Respeito aos superiores e aos mais velhos, virtude descrita na página 273 , conforme o autor, garante a ordem social e a prosperidade pública, pois atesta que os alunos saibam respeitar os mais velhos e as figuras superiores da província (membros do clero, chefes e donos de fábricas). A última virtude, respeito à lei e aos magistrados, segundo Daligault, deve ser transmitida pelo professor aos alunos ao conceituar o que é lei e quais são suas vantagens para a sociedade. Descrita como uma forma de assegurar a ordem social, Daligault define:

Revoltar-se contra a lei, é pois, atacar a própria sociedade; é querer arruinála, e destruí-la; pois que sem uma lei, seja ela qual for, não é possível haver sociedade; conseguintemente, é fazer um ato, que tende a aniquilar todos os frutos da civilização (DALIGAULT, 1870, p. 275).

Esse conjunto de virtudes morais que se destina à orientação de professores de escolas de primeiras letras evidencia um modelo de sociedade que tem na lei e na religião os elementos garantidores da ordem social. Essas virtudes, se incorporadas, garantem a manutenção do poder para aqueles que detêm o poder econômico, pois, naquele momento, no Brasil, a lei assegurava acesso ao poder somente àqueles que detinham determinado patrimônio. Se a lei é incorporada como verdade, deve ser respeitada assim como se respeita a Deus, logo, a manutenção da ordem social estaria garantida. Em outras palavras, a instrução oferecida nas escolas era instrumento para manutenção da ordem social estabelecida.

Xavier (1992, p. 110), ao abordar a realidade brasileira do século XIX como resultado da manutenção da dependência colonial, afirma que, nas relações deste período, não deixaram de acontecer formas de controle, do mesmo modo que aconteciam no período colonial. Agora, essas não aconteciam apenas por poderio político, mas "pela aliança econômica com a classe dominante nacional”.

Além disso, a mesma autora observa que, nesse período, passou a acontecer a dependência cultural como estratégia para controlar e manter o quadro hierárquico de organização social.

Daí a escola, como centro distribuidor de cultura por excelência, ter sido a instituição basicamente afetada pelo transplante: a sua organização, os seus conteúdos, os seus métodos, a própria legislação escolar, enfim, passou, mais do que nunca, a consagrar os modelos alheios. Também a cultura constituía-se num bem a ser consumido, e a legislação e as instituições escolares, em consequência, assumiram um caráter 'autônomo' e alienado em relação à realidade nacional (XAVIER, 1992, p. 110, grifo da autora).

Sobre o "objeto da missão do professor", na página 18 do manual, Daligault comenta três aspectos a considerar na formação dos alunos: força física, razão e o entendimento do professor sobre o que é felicidade para os alunos (DALIGAULT, 1870, p. 18).

A força física é descrita como uma vantagem para a vida daqueles que fazem parte da classe operária, "condenada a procurar no mais rude trabalho o seu pão cotidiano" (DALIGAULT, 1870, p. 18). Além disso, o autor menciona a necessidade de a força física ser trabalhada pelo professor com seus alunos, pois 
[...] Conquanto o vigor do corpo seja principalmente um dom da natureza, e também um dos resultados da educação, o Professor pode até certo ponto fazer conseguir, ou garantir a seus jovens discípulos esta riqueza do pobre, que preservando-os, por uma contínua vigilância, de toda a influência prejudicial à saúde (DALIGAULT, 1870, p. 18).

Ao considerar a Educação Física conforme descrita no manual, fica evidente a intencionalidade em manter a estrutura social existente. Isso possibilita a disciplina para os estudos e, além disso, o condicionamento físico adequado para aqueles que forem utilizá-lo em seu trabalho, para que saibam debruçar-se na labuta árdua, sem revoltar-se pela sua condição social, já que ela é vontade divina.

O professor, nesse processo, também é instrumento de manutenção e afirmação dos modos de ser e estar das classes que ocupam a ordem social dominante no século XIX. Deve ensinar seus alunos a pensar, refletir e raciocinar a partir de determinados princípios, enfatizando que as diferenças entre as classes sociais são naturais ou resultado da vontade divina, transmitindo os conhecimentos necessários para cada um cumprir o seu destino.

Nesse sentido, no manual, o papel do professor é disseminar uma cultura escolar que favoreça a manutenção das relações de dominação.

De acordo com Mattos (2012),

[...] A cultura (o singular é importante) é aí entendida como oposta à barbárie - e, nos quadros do Iluminismo, às explicações de base religiosa do mundo - e associada a um caminho de evolução progressiva do conhecimento humano universal, banhado pelas verdades oriundas de um conhecimento científico/positivo que tenderia [a] superar as traduções obscurantistas das visões de mundo primitivas dos povos incivilizados. Contraditoriamente, tal concepção pôde tanto justificar a superação das bases ideológicas do domínio senhorial do Antigo Regime, quanto ser invocada para apresentar como missão civilizatória a sanha de exploração neocolonial e imperialista (MATTOS, 2012, p. 118-119).

Ao descrever como o professor deve entender o que é a felicidade para seus alunos, Daligault a cita como uma virtude que deve ser transmitida a eles, compreendendo seu trabalho como uma missão e reconhecendo as crianças como um "solo virgem" em que se deve lançar "uma preciosa semente, que produzirá os mais felizes frutos" (DALIGAULT, 1870, p. 19).

Neste momento, mesmo que Daligault não apresente uma definição sobre a infância, deixa claro que são seres ingênuos, desprovidos de conhecimento e que devem se tornar adultos para cumprir o seu destino.

Sobre a felicidade, Daligault completa:

[...] o Preceptor concorre com o Sacerdote na sublime missão, que lhe está confiada, de conduzir suas ovelhas ao supremo fim de todos os homens neste mundo. Como o Sacerdote ele narra a seus discípulos, ou jovens alunos, as infinitas grandezas de Deus, e a magnificência de suas recompensas; como Sacerdote faz-lhes apreciar o imenso benefício da Redenção, e amar a doutrina Santa do Divino Redentor; como Sacerdote os inicia, mais ainda pelo exemplo do que com as lições, na prática de todas as virtudes cristãs; e como o Sacerdote enfim lhes mostra o Céu, e abre o caminho que a ele conduz (DALIGAULT, 1870, p. 20). 
O professor, através do exemplo, torna-se para os alunos uma referência de vida cristã. $\mathrm{E}$ a felicidade, neste caso, é uma virtude ancorada na crença religiosa, pois, ao crer em Deus e considerá-lo a entidade superior que decide sobre a natureza das coisas, é possível que a condição de submissão e subalternidade vivida aconteça sem a necessidade de ser questionada. Contrário à oportunidade de emancipação, o professor, seguindo este papel a ele designado, contribui para que se mantenha estático o lugar ocupado por cada classe social. Os integrantes da classe pobre, ao seguir os ensinamentos de Deus, conseguirão, ao fim de suas vidas, ir para um lugar que não é mais dividido por classes, o céu. Assim, seriam gratificados com uma redenção, como gratificação por terem suportado a opressão e subalternidade.

\section{Qualidades necessárias ao professor de primeiras letras}

Outro elemento que fundamenta o papel do professor como formador de virtudes pode ser percebido no momento em que são descritas as qualidades necessárias ao professor. Antes de comentar quais são, Daligault afirma que

as qualidades, cuja necessidade queremos demonstrar, são essas virtudes morais e religiosas, que qualquer homem, que tenha boa vontade, pode adquirir pela reflexão, a experiência, a vigilância sobre si mesmo, e principalmente recorrendo para Deus (DALIGAULT, 1870, p. 22).

Para descrevê-las, o autor divide-as em qualidades que se referem diretamente às funções do professor e qualidades que se referem indiretamente às suas funções.

A denominação direta relaciona-se às qualidades que são obrigatórias para o professor organizar o ambiente de ensino e ministrar suas aulas. Já as qualidades indiretas, são as que dizem respeito ao modo de ser do professor, ao exemplo que deve ser na sociedade, sendo um homem religioso e de vida simples, porém honrosa.

Assim, as definições do papel do professor no manual indicam que, antes de transmitir os conteúdos aos alunos, deve transmitir as virtudes e, para que isto aconteça, é imprescindível que o professor tenha qualidades que assegurem a prática de virtudes em sua vida cotidiana, seja no âmbito pessoal ou social.

As qualidades diretas são: bondade, firmeza, paciência, regularidade, zelo, pureza de costumes e piedade cristã (DALIGAULT, 1870, p. 22).

A bondade acontece através de uma relação afetiva, pois, ao demonstrar-se bondoso, o professor torna-se confiável para seus alunos. Ao ser bondoso, o professor reconhece a ingenuidade, a timidez e as fraquezas das crianças, e coloca-se em uma posição de guia para suas ações, no presente e no futuro, atendendo ao ideal de uma formação que vise à moralidade (DALIGAULT, 1870, p. 23).

A firmeza é utilizada para definir uma relação respeitosa dos alunos com o professor, visto que, além de ser amado por seus alunos, o professor deve ser respeitado. Essa qualidade acontece através do posicionamento do professor enquanto uma alma enérgica para manter o ambiente escolar equilibrado, em que os alunos reconhecem o professor como autoridade e respeitam as normas escolares previstas (cumprir horários, momentos de silêncio, de orações, de oratória, etc.). Além disso, percebendo a "mesquinhez de ideias" de seus alunos, diante da persistência em atitudes inadequadas, o professor deve fazer punições sem gerar constrangimentos (DALIGAULT, 1870, p. 24). Nesta qualidade, fica evidente a figura de autoridade do professor em relação aos alunos, questão importante no contexto do período 
onde a hierarquia social, e principalmente, a obediência às autoridades e às leis, devem ser observadas por todos.

A paciência é outra qualidade a ser praticada pelo professor, uma vez que o ajudará nas dificuldades de sua trajetória, como, por exemplo, os defeitos (mentira, preguiça, modos grosseiros de vestir e de falar) que alguns alunos apresentarem. Conforme Daligault, o professor deverá ser paciente ao ensinar, porquanto determinados assuntos precisam ser repetidos diversas vezes, até serem compreendidos (DALIGAULT, 1870, p. 26). A busca pela paciência deve acontecer consigo mesmo e com Deus. Daligault afirma que a fé é importante para que essa virtude seja mantida, pois "quando sentir, que a coragem lhe falece, ou que a paciência lhe escapa, bastará uma aspiração para o céu, e um movimento de olhos para o Crucifixo, para acalmá-lo" (DALIGAULT, 1870, p. 26-27). Outra forma de assegurar a compreensão do professor sobre a necessidade de ser paciente é citada pelo autor ao lembrar que as atitudes indisciplinares, muitas vezes, são provenientes da má educação que recebem em casa (DALIGAULT, 1870). A escola, nesse sentido, educa aqueles que em sua casa não recebem as virtudes como preceitos. A paciência remete ao professor de primeiras letras a aceitação da falsa consciência que projeta nele a responsabilidade pela formação social dos alunos enquanto futuros cidadãos. Mészáros contribui nesse sentido, ao dizer que:

[...] o que se espera das autoimagens da ideologia dominante não é o verdadeiro reflexo do mundo social, com a representação objetiva dos principais agentes sociais e seus conflitos hegemônicos. Antes de tudo, elas devem fornecer apenas uma explicação plausível, a partir da qual se possa projetar a estabilidade da ordem estabelecida (MÉSZÁROS, 2004, p. 69, grifos do autor).

Assim, o professor paciente e responsável em conduzir seus alunos às virtudes parte do entendimento de que, antes de chegarem à escola, estes pouco ou nada conheciam sobre o assunto, mas, com o seu trabalho, eles passam a adotar as virtudes como usuais em seu cotidiano, podendo se tornar cidadãos aptos ao convívio social, dentro dos padrões estabelecidos pelos dirigentes daquele período. Sobretudo, esses preceitos possibilitam a manutenção da ordem social estabelecida, mascarando a realidade heterogênea existente no momento histórico em questão.

A regularidade, outra qualidade importante para o professor, pode ser resumida no cumprimento das atividades dentro dos $\operatorname{prazos}^{5}$, e na assiduidade e pontualidade do professor em seus compromissos na escola, pois, na ausência do professor, os alunos podem causar acidentes e fazer travessuras (DALIGAULT, 1870, p. 28). Num momento em que o tempo passa a ser controlado em função do novo modelo de produção em processo inicial de implantação no Brasil, a precisão e regularidade nas atividades escolares não, necessariamente, buscavam a ordem na escola. Através da ordem construída nas escolas, regia-se a disciplina do sujeito para a vida social.

Outra qualidade direta era o zelo, definido por Daligault como a acuidade que o professor precisa ter para cumprir suas obrigações. Algumas formas para a efetivação desta qualidade são: preparar as lições antes das aulas, entender as dificuldades dos alunos e auxiliá-los, esforçar-se para tornar as aulas "apreciáveis e encantadoras" (responder a perguntas sem se mostrar cansado, dar exemplos durante as aulas, explicar os conteúdos claramente), não gritar em sala, dedicar algumas horas vagas para momentos de estudo em busca de enriquecer-se de ideias e aumentar o vocabulário, e ser cauteloso para não infringir e não permitir que os alunos desrespeitem regras (DALIGAULT, 1870, p. 30-31). 
Ao descrever as atribuições que tornam o professor um profissional zeloso, Daligault indica que a dedicação do professor ao seu trabalho deve ir além dos momentos em que acontecem as aulas para as quais é contratado pelo governo provincial. A ampliação do conhecimento, do vocabulário e também a preparação das aulas que serão dadas deve acontecer nos espaços de tempo em que o professor não está em sala de aula, ou seja, seu tempo livre deve ser também direcionado para preparação e composição de uma postura que é modelo de representação social. Além disso, o zelo do professor também é uma virtude para a formação do coração, conseguida pela vigilância sistemática e a condução para a prática de costumes "puros”, através da pureza de costumes (DALIGAULT, 1870, p. 33).

Assim, a pureza de costumes serve para o professor transmitir as virtudes aos alunos, na intenção de que, possuindo-as, eles estejam próximos do ideal de cidadão previsto pelos dirigentes do período. Formar o coração é transmitir normas de condutas para a organização social. Esta não se restringe à dimensão de uma consciência puramente racional, mas também afetiva e moral.

Thompson (1981) faz referência a esses conceitos descritos por Daligault como elementos do papel do professor, quando fala acerca de cultura. Para ele,

[...] as pessoas não experimentam sua própria experiência apenas como idéias, no âmbito do pensamento e de seus procedimentos, ou (como supõem alguns praticantes teóricos) como instinto proletário, etc. Elas também experimentam sua experiência como sentimento e lidam com esses sentimentos na cultura, como normas, obrigações familiares e de parentesco, e reciprocidades, como valores ou (através de formas mais elaboradas) na arte ou nas convicções religiosas. Essa metade da cultura (e é uma metade completa) pode ser descrita como consciência afetiva e moral (THOMPSON, 1981, p. 189).

A última qualidade direta é a piedade cristã, a qual Daligault utiliza para fundamentar o trabalho do professor como intrínseco à religião. O professor que não possui religião deve ter a moralidade contestada, pois a falta de uma postura religiosa torna o homem suscetível aos vícios (DALIGAULT, 1870, p. 35). Assim, o interessado na profissão deve seguir pressupostos religiosos, e encarar a profissão docente como uma carreira que está vinculada à religiosidade enquanto missão de fé:

Eis aqui a consciência destas diversas reflexões: Todo o jovem que se não sente inteiramente virtuoso, que não é sincera e profundamente religioso, não deve pensar jamais em entrar na carreira do ensino, porque aí nada de bom poderá fazer, sejam quais forem suas qualidades, porque em vez de dirigir a mocidade, a desviará do bom caminho, e finalmente porque nesta carreira não poderá alcançar para si mesmo nem consideração, nem felicidade (DALIGAULT, 1870, p. 38).

A religiosidade, neste caso, é uma característica indispensável para aqueles que pretendem ser professores, visto que asseguraria o exercício dos bons costumes instituídos como essenciais para o bom andamento da sociedade. Do mesmo modo, a religião, como alicerce ao trabalho do professor, possibilitaria que os alunos estivessem mais próximos dos hábitos virtuosos, do convívio social harmônico e de se tornarem pessoas civilizadas e ordeiras.

Nessa perspectiva, os conhecimentos a serem transmitidos para o desenvolvimento de virtudes conduzem a uma formação passiva: além das disciplinas asseguradas por lei, o 
papel do professor compreendia a transmissão de conhecimentos sobre a religiosidade como elemento indispensável para os alunos tornarem-se cidadãos aptos a conviver em sociedade.

A educação prevista no manual pretende estabelecer uma relação harmoniosa entre as classes sociais, haja vista o entendimento de que Deus é responsável pelo destino que cada homem deve cumprir aqui na terra, seja este de sacrifícios ou de bonança.

Emilia Viotti da Costa em seu livro Da Monarquia a República (1999), contribui para melhor compreender o papel da religião na instrução elementar. Segundo ela, a religião católica é definida pelo Estado brasileiro como a religião oficial. Por isso, seus ideais são difundidos no sistema de ensino, que ainda não é, de fato, um sistema, e não identifica a laicidade como necessária. Praticar os costumes religiosos, nesse contexto, é a forma mais profícua para expressar o quanto se é um cidadão de bem e se preza pelos bons costumes.

Desse modo, rezar, frequentar a igreja, acreditar em Deus como o único provedor do destino dos homens, amar primeiro a Deus e depois aos seus, ser caridoso, doando objetos e comidas para aqueles que precisam, respeitar objetos que remetam à figura da religião como se fossem o próprio Deus - por exemplo, o crucifixo -, aceitar a condição escolhida pelo Senhor como algo necessário, respeitar sacerdotes devido ao fato de serem correspondentes de Deus na terra, etc., passam a ser consideradas atitudes naturais.

Além das qualidades diretas consideradas necessárias para o professor desempenhar seu papel, "[...] há outras que assegurando-lhe no seu distrito a estima e simpatia dos habitantes, contribuem por isso para o bom resultado do ensino", como as qualidades indiretas: polidez, modéstia, prudência, desinteresse e amor à solidão (DALIGAULT, 1870, p. 39).

As qualidades indiretas são formas de ser e estar que devem ser incorporadas pelo professor para assegurar a sua imagem exemplar perante a sociedade. Ao mesmo tempo, evidencia que o magistério deve ser assumido como um sacerdócio através do qual, por vocação, o professor assume as características necessárias para ser um homem temente às designações dos superiores, sendo estes os representantes da Igreja Católica, os dirigentes da província e Deus.

A primeira qualidade indireta ao trabalho do professor é a polidez, que assegura que o professor "seja do seu século, e sobretudo do seu país", um membro formador da civilização e que, diante desta função, deve demonstrar respeito à pátria. Daligault diz que o professor deve se apresentar de forma polida até mesmo nos ambientes em que a polidez ainda não é frequente, com a intenção de que seja provido exemplo não somente aos alunos, mas às demais pessoas que forem de seu convívio (DALIGAULT, 1870, p. 39). Esta qualidade, então, afirma a missão do professor em ser uma figura exemplar para a sociedade, fruto de uma consciência afetiva e moral.

A modéstia está diretamente ligada ao modo de o professor falar, vestir-se e apresentar-se na escola e em lugares públicos, uma vez que ele deve ter simplicidade em seus costumes. Além disso,

[...] Evitará também esses modos extravagantes de trazer os cabelos, ou a barba, os quais, além de fraqueza de espírito, revelam um desejo de agradar, sem termos e sem moderação. Privar-se-á, tanto em público, como em particular do uso desagradável e oneroso do cigarro e do cachimbo [...] (DALIGAULT, 1870, p. 44, grifos do autor).

Ao consentir na simplicidade de costumes, o professor assegura uma imagem na sociedade como a de um homem puro e livre de vícios e caprichos comuns aos demais, aproximando-o da vocação exigida pelo sacerdócio. Com isso, evita más interpretações dos 
alunos e da sociedade, colocando-o na condição de uma pessoa, naturalmente, vocacionada para sua profissão e exemplo a ser seguido.

À simplicidade de costumes deve ser adicionada a prudência, qualidade que o cuidado do professor em relação à sua imagem pública. Sobre isso, Daligault explica que o professor não deve frequentar bares, deve evitar a ingestão de bebidas alcoólicas, deve ser cuidadoso ao falar em público, respeitar as autoridades públicas ${ }^{6}$ e manter uma relação respeitosa com os demais entes da sociedade, pois ações contrárias a essas são motivos para que as famílias desconfiem de sua índole (DALIGAULT, 1870, p. 47).

Essa prudência determina que o lugar ocupado na sociedade por cada sujeito é definidor de sua condição social. A prudência é, então, a atenção que o professor deve ter sobre o lugar que ele ocupa na sociedade, sobre as ordens que ele deve seguir e, principalmente, sobre o posicionamento político neutro que deve possuir.

A penúltima qualidade descrita por Daligault como indireta ao trabalho do professor é o desinteresse. Esta garante que o professor "se preserve de certa rispidez por amor do lucro", pois o interesse material "é incompatível com a nobreza dos sentimentos" (DALIGAULT, 1870, p. 51, grifos do autor). Assim ${ }^{7}$, conquistas materiais não devem ser o objetivo de vida do professor, que deve aceitar uma condição financeiramente modesta e, em caso de descontentamento, deve deixar a profissão, sob pena de não ser um bom professor, ao não compreender essa virtude.

A adoração dos alunos pelo professor, portanto, não é empregada ao professor por sua personalidade e suas características individuais, mas pelo que representa através de suas virtudes e valores praticados socialmente.

Por fim, com a qualidade amor à solidão, fundamentada na necessidade de o professor ter relações sociais harmônicas, Daligault afirma que "a vida do Professor deve conservar-se em harmonia com as exigências das funções que exerce", o professor deve evitar o "excesso de familiaridade" com as famílias de seus alunos para não perder o seu prestígio de autoridade, e deve ocupar seu tempo com atividades que não prejudiquem sua imagem de seriedade perante a sociedade (DALIGAULT, 1870, p. 53, grifos do autor).

$\mathrm{O}$ autor menciona que o amor à solidão é uma qualidade difícil de ser seguida, mas diz que, "se ele compreender porém os seus deveres, ou para melhor dizer, se compreender bem os seus verdadeiros interesses, resistirá com eficácia a todas às suas instâncias" (DALIGAULT, 1870, p. 53, grifos do autor). Ademais, na expectativa do melhor aproveitamento do tempo livre dos professores, para exercer o amor à solidão, relata:

Dever-se-á porventura proibir ao Professor toda e qualquer espécie de recreio? Não por certo, mas é mister que busque ordinariamente seu repouso e refrigério na sociedade de alguns amigos bem escolhidos, e principalmente no interior de sua casa. Se tiver família, ocupará suas horas vagas de um modo igualmente útil e agradável nos cuidados e afeições domésticas. Se não a tiver porém, encontrará suaves e inocentes gozos na conservação de seu jardim, na cultura das flores, ou enxerto e poda das árvores, em cuja ocupação, além disto, achará os meios de reduzir à prática os conhecimentos teóricos, que houver recebido na Escola Normal (DALIGAULT, 1870, p. 54, grifos do autor).

Essa qualidade, junto com as demais, sugere que Daligault entende que as relações sociais interferem na constituição do sujeito, sendo, então, necessário definir quais são "saudáveis" para aqueles que pretendem ser professores em uma sociedade onde a barbárie deve dar lugar à civilização. 


\section{Considerações finais}

A partir da independência política do país, em 1822, tornou-se obrigação do Estado oferecer escola elementar para a população. Havia necessidade de criar uma opinião homogênea em prol dos interesses do Estado brasileiro. As ideias propagadas na época certificavam que da instrução dependiam os progressos civilizadores, materiais e políticos de uma nação.

Após a Independência, as decisões seriam tomadas a partir de leis definidas pelo Estado e não mais com base nas vontades individuais de determinadas pessoas. No dizer de Ilmar de Mattos, o governo da Casa - mundo privado - e o governo do Estado - mundo público - deveriam ser separados. Este último deveria ser exercido sobre toda a população e tinha no poder central sua expressão máxima. As administrações locais eram extensões daquela. "Os sempre vigilantes olhos do imperador eram a condição para o triunfo da Ordem, possibilitando a difusão da Civilização; o triunfo da Civilização era a condição para a difusão dos valores de uma Ordem" (MATTOS, 1990, p. 193).

Assim, a educação escolar era apresentada nos discursos da elite dirigente do período como uma premissa e uma necessidade das nações em processo de constituição.

O sonho de uma sociedade de costumes moderados, em que a tranquilidade pública se instauraria pela sobriedade, continência e equilíbrio - virtudes que se opunham à turbulência e à desorganização - poderia, no entender da elite ilustrada, ser concretizado pela ação educativa (SHAFASCHECK, 1997).

Na busca por constituir uma nação civilizada, a aquisição e tradução do manual de Pedagogia de Daligault parecem ser bastante apropriadas. Sua origem francesa asseguravalhe uma representação da civilização, ao mesmo tempo em que seu conteúdo continha os elementos necessários à formação de um professor adaptado a esse projeto de nação.

O papel do professor, no manual de Daligault, tem nas virtudes e valores seu referencial, tanto para as ações pedagógicas como para a vida pessoal. A origem dessas virtudes advém da religião católica, definida, naquele momento, como religião oficial do Estado.

Mesmo que diferentes nações europeias consideradas civilizadas praticassem, naquele período, a instrução pública sob a premissa da laicidade, o Estado brasileiro e a província de Santa Catarina reafirmavam a necessidade da religiosidade na educação, conferindo a crença em Deus como fundamento para aceitação da condição social em que os indivíduos estavam inseridos.

O papel do professor, portanto, conforme definido no manual, deveria ser baseado nos fundamentos da fé cristã. Sobretudo, que o professor de primeiras letras possuísse uma postura de dedicação, tornando-se exemplo de vida para aqueles que lhes fora confiada a educação.

Para isso, suas virtudes, identificadas nos modos de andar e de vestir, não prescindiam de algumas condições classificadas por Daligault como qualidades diretas e indiretas. As primeiras referem-se às qualidades obrigatórias para o professor organizar o ambiente de ensino e ministrar suas aulas. Já as qualidades indiretas, são as que dizem respeito ao modo de ser do professor no contexto social, expressão de sua postura exemplar na sociedade. 
Nessa perspectiva, os conhecimentos transmitidos para o desenvolvimento de virtudes conduzem a uma formação passiva, principalmente pela inclusão dos princípios religiosos como fundantes para as futuras gerações.

Pode-se dizer que o professor tem na formação de virtudes a maior responsabilidade de seu magistério, dado que esta era destinada a todas as crianças. A formação intelectual, por sua vez, continuava restrita aos filhos da elite, que, regra geral, recebiam-na em suas casas, por preceptores contratados pela família.

\section{Referências}

BASTOS, M. H. C. Manuais escolares franceses no Imperial Colégio de Pedro II (1856 1892). Revista História da Educação. ASPHE/FaE/UFPel, Pelotas, v. 12, n. 26, p. 39-58, set./dez. 2008. Disponível em: 〈http//fae.ufpel.edu.br/asphe〉. Acesso em: 10 fev. 2015.

COSTA, E. V. da. Da monarquia à república: momentos decisivos. 7. ed. São Paulo: Fundação Editora da UNESP, 1999.

DALIGAUlT, J. B. Curso Prático de Pedagogia: destinado aos alumnos das Escolas normaes primarias, Aspirantes ao Magisterio, e aos Professores em exercicio. 2. ed. Santa Catarina: Typografia de Ribeiro \& Caminha. 1870. 279p. Disponível em:

<http://www.bu.ufsc.br/projeto_obras_raras/37894.pdf >. Acesso em: 10 jun. 2015.

MATOS, M. B. E. P. Thompson e a tradição de crítica ativa do materialismo histórico. Rio de Janeiro: Editora UFRJ, 2012.

MATTOS, I. R. de. O Tempo Saquarema - A formação do Estado Imperial. 2. ed. São Paulo: Hucitec, 1990.

MÉSZÁROS, I. O poder da Ideologia. São Paulo: Boitempo Editorial, 2004.

SAVIANI, D. Formação de professores: aspectos históricos e teóricos do problema no contexto brasileiro. Revista Brasileira de Educação, v. 4, n. 10, p. 143-150, 2009.

SCHAFASCHEK, R. Educar para civilizar e instruir para progredir - Análise de artigos divulgados pelos jornais do Desterro na década de 1850. 1997.

Dissertação (Mestrado em Educação)-Universidade Federal de Santa Catarina, Florianópolis, 1997.

SCHMIDT, L. L.; SCHAFASCHEK, R.; SCHARDONG, R. A educação em Santa Catarina no século XIX: as escolas de instrução elementar e secundária e os debates nos jornais da época. Florianópolis: DIOESC, 2012.

SILVA, V. L. G. Os sentidos da formação docente: estudo comparado acerca de sentidos da profissão docente do ensino primário, envolvendo Santa Catarina, São Paulo e Portugal na virada do século XIX para o século XX. Tese (Doutorado em Educação)-Universidade de São Paulo, São Paulo, 2004. 
SOUZA, R. F. de; VALDEMARIN, V. T. e; ALMEIDA, J. S. de. O Legado Educacional do Século XIX. Araraquara: UNESP - Faculdade de Ciências e Letras, 1998.

THOMPSON, E. P. A miséria da Teoria ou um planetário de erros (uma crítica ao pensamento de Althusser). Tradução de Waltensir Dutra. Rio de Janeiro: Zahar Editores, 1981.

TREVISAN, T. A.; PEREIRA, B. C. Manuais de ensino franceses e brasileiros para o ensino da leitura e escrita no Brasil (1851 - 1966). In: CONGRESSO BRASILEIRO DA HISTÓRIA DA EDUCAÇÃO, v. 6, 2011, Vitória: SBHE, 2011. Anais eletrônicos... Disponível em: <http://www.docstoc.com/docs/158802165/1219>. Acesso em: 20 mar. 2015.

VEIGA, C. G. A escolarização como projeto de civilização. Revista Brasileira de Educação, n. 21, p. 90-103, 2002. Disponível em:

<http://www.scielo.br/pdf/rbedu/n21/n21a07.pdf>. Acesso em: 01 dez. 2014.

XAVIER, M. E. S. P. Poder político e educação de elite. 3. ed. São Paulo: Cortez Editora, Autores Associados, 1992. 
Notas

\footnotetext{
${ }^{1}$ Mestre em Educação e professora de Educação Básica.

2 Doutora em Educação pela PUC/SP e Professora do Programa de Pós-Graduação em Educação - Mestrado em Educação da Unisul.

${ }^{3}$ Desterro é atualmente Florianópolis, capital do estado de Santa Catarina.

${ }^{4}$ Essa parte do manual define os defeitos dos meninos que devem ser banidos, as virtudes morais e as virtudes religiosas que devem ser transmitidas pelo professor e os meios que devem ser usados para assegurar e fortalecer a educação moral e religiosa.

${ }^{5} \mathrm{O}$ tradutor Franc de Paulicéa Marques de Carvalho (em nota de rodapé) informa que os prazos podem ser encontrados no Regulamento de 28 de abril de 1868, em Santa Catarina.

${ }^{6}$ Dirigentes da província e representantes da Igreja Católica.
}

Recebido: Abril/2016.

Aprovado: Junho/2017. 